\title{
A POLITIZAÇÃo DO JUDICIÁRIO E A JURIDICIZAÇÃO DO POLÍTICO NA SOCIEDADE CONTEMPORÂNEA: O SIGNIFICADO DA INTERPRETAÇÃO E O PAPEL DOS JUÍZES NA CRIAÇÃO DO DIREITO, EM TEMPOS DE DEMOCRACIA DELIBERATIVA
}

\author{
POLITIZATION OF JUDICIARY AND LEGALIZATION OF POLICY IN CONTEMPORARY \\ SOCIETY: THE MEANING OF INTERPRETATION AND THE ROLE OF JUDGES IN THE \\ CREATION OF LAW IN TIMES OF DELIBERATIVE DEMOCRACY
}

\section{Pedro Manoel Abreu}

Mestre e Doutor pela Universidade Federal de Santa Catarina - UFSC; Pós-doutor pela Universidade de Lisboa;

Professor do Programa de Mestrado e Doutorado em Ciência Jurídica da Universidade do Vale do Itajaí Univali;Professor da Academia Judicial em Cursos de formação inicial e continuada de magistrados do Centro de Estudos Jurídicos - CEJUR - do Tribunal de Justiça de Santa Catarina; Professor convidado do Curso de Mestrado Profissional em Direito da UFSC.

E-mail: pedromanoel.abreu@gmail.com

Recebido em: 01/07/2019

Aprovado em: 09/12/2019

RESUMO: O presente artigo propõe questões centrais da teoria política e da teoria jurídica na demarcação dos limites da representação em face de dois fenômenos contemporâneos - a denominada judicialização da política e a politização do jurídico, que parecem subverter a clássica divisão dos poderes concebida pelo Estado liberal. Outra questão importante diz respeito à delimitação dos espaços dos diversos sistemas - político, jurídico e econômico - objeto de interferências recíprocas, apontadas como razão de uma verdadeira crise da representação. Nessa perspectiva, é fundamental reforçar algumas conclusões já acenadas difusamente em pesquisas anteriores pelo autor, ressaltando a questão da politização do judiciário e a juridicização do político, principalmente na sociedade brasileira e, finalmente, uma questão adjacente que diz respeito à interpretação e a criação do direito pelos juízes, no exercício da jurisdição democrática, nessa quadra da vida nacional e nesses tempos complexos da pós-modernidade de democracia deliberativa.

Palavras-chave: Direito;Politização do Judiciário; Juridicização do político; Democracia.

ABSTRACT:This article proposes central questions of political theory and legal theory in the demarcation of the limits of representation in the face of two contemporary phenomena - the socalled judicialization of politics and the politicization of the legal system, which seem to subvert the classical division of powers conceived by the liberal state. Another important question concerns the delimitation of the spaces of the various systems - political, juridical and economic subject to reciprocal interference, pointed as the reason for a true representation crisis. In this perspective, it is fundamental to reinforce some conclusions that have been diffused in previous researches by the author, emphasizing the question of the politicization of the judiciary and the juridicization of the politician, mainly in the Brazilian society and, finally, an adjacent question 
that concerns the interpretation and the creation of the right by the judges, in the exercise of democratic jurisdiction, in this stage of national life and in these complex times of postmodern democracy of deliberative democracy.

Keyword: Law;Politicization of the Judiciary, Juridicization of the politician; Democracy.

\section{INTRODUÇÃO}

Uma das questões centrais da teoria política e da teoria jurídica é a demarcação dos limites da representação em face de dois fenômenos contemporâneos - a denominada judicialização da política e a politização do jurídico, que parecem subverter a clássica divisão dos poderes concebida pelo Estado liberal. Outra questão importante diz respeito à delimitação dos espaços dos diversos sistemas - político, jurídico e econômico - objeto de interferências recíprocas, apontadas como razão de uma verdadeira crise da representação.

O Judiciário, na democracia contemporânea, de outra parte, tem um papel indeclinável. Concebido autonomamente, numa visão liberal de divisão de funções, fundante do Estado moderno, assume novos papeis nesse novo patamar civilizatório, transformando-se num locusda cidadania inclusiva e de concretização de direitos proclamados na Constituição e passíveis de efetivação no processo. ${ }^{1}$

Essa tendência contemporânea traduz uma radical mudança de perfil do Judiciário, que passa a ter um crescente envolvimento com a questão social, abdicando progressivamente de uma postura positivista-normativista, que o tornava um poder periférico, distante da agenda política e dos atores sociais, para tornar-se, agora, uma instituição central à democracia, especialmente a brasileira (ABREU, 2011, p. 246-247) Ademais, facultado o controle abstrato de constitucionalidade das normas à comunidade dos intérpretes, o Judiciário passa a ser apreendido como um estuário para as insatisfações políticas, notadamente pelo ativismo legislativo pelo Executivo, e assume um papel constitucional que o identifica como guardião da Constituição e dos valores fundamentais da República (VIANNA, 1999, p. 11), exercitando uma representação funcional e argumentativa (deliberativa).

Os temas aqui abordados têm sido objeto de pesquisa do autor nos últimos anos, seja no doutoramento, exercício da cátedra, em conferências e debates acadêmicos, inclusive com magistrados, seja em cursos de formação inicial, continuada e especialização de juízes, patrocinados pelo Centro de Estudos Jurídicos - CEJUR e Academia Judicial do Tribunal de Justiça do Estado de Santa Catarina.

Nesse compasso, o autor tem procurado decifrar os caminhos do judiciário brasileiro nesses tempos de ativismo judicial evidente, inclusive em matéria de políticas públicas, e mais intensamente a tendência de normatização das decisões dos tribunais, principalmente pelo STF e STJ (via Repercussão Geral e Recursos Repetitivos), e de dogmatização crescente das decisões pela adoção do sistema de precedentes pelo novo Código de Processo Civil.

Nessa perspectiva, é fundamental reforçar algumas conclusões já acenadas difusamente em pesquisas anteriores, ressaltando a questão da politização do judiciário e a juridicização do político, principalmente na sociedade brasileira e, finalmente, uma questão adjacente que diz respeito à interpretação e a criação do direito pelos juízes, no exercício da jurisdição democrática, nessa quadra da vida nacional e nesses tempos complexos da pós-modernidade de democracia deliberativa.

${ }^{1}$ Sobre o assunto, ver: (ABREU, 2016, p. 84).

Revista de Direito Brasileira | Florianópolis, SC | v. 23 | n. 9 | p.50-62 |Mai./Ago. 2019 


\section{A POLITIZAÇÃo DO JUDICIÁRIO E A JURIDICIZAÇÃo DO POLÍTICO NA SOCIEDADE CONTEMPORÂNEA}

A desneutralização, a emergência de seu ativismo e, sobretudo a judicialização da política são processos afirmativos do Judiciário, em escala mundial, compreendendo tanto os sistemas de common lawcomo os de civil law, constituindo-o, no vaticínio de Cappelletti, no "Terceiro Gigante". O Judiciário, seja como ator coletivo, seja através do trabalho heróico e compassivo do juiz individual, "abandona o seu canto neutro e se identifica com a preservação dos valores universais em uma sociedade que cada vez menos se reconhece no seu Estado, em seus partidos e no seu sistema de representação" (VIANNA, 1997, p. 39).

No plano político um dos temas recorrentes na atualidade é justamente a discussão acerca da capacidade de intervenção do Judiciário no âmbito das questões governamentais. Assuntos habitualmente circunscritos à arena política estariam sendo objeto de decisões judiciais. Por isso, fala-se em governo de juízes, judiciarismo, judicialização, judiciocracia, ativismo judicial, juridicização do fato político, dentre outros termos, que retratam essa expansão do Poder Judiciário, fenômeno apontado como um dos mais notórios fatos políticos da atualidade.

O limite entre o político e o judicial, para Eugenio RaúlZaffaroni, não pode ser definido formalmente no Estado moderno. A justiça moderna não pode ser apolítica, mesmo porque é inarredável o reconhecimento de que o poder judiciário é governo. A definição do judiciário, por isso, não pode ser estabelecida "na afirmação de que não estabelece regras erga omnes, de que não é co-legislador" (ZAFFARONI, 1995, p. 24-25), porquanto a realidade tem demonstrado que não lhe resta, às vezes, outro recurso do que sê-lo (BIELSA, 1984, p. 87).

Numa visão sistêmica, para Luhmann (1980), a sociedade sempre foi uma rede de comunicações. Entretanto, na percepção de Campilongo, os modos de organização dessa rede variaram historicamente e somente na modernidade foram estabelecidos critérios funcionais, com a estabilização de sistemas especializados, como o direito, a política e a economia. Como conseqüência da realidade de uma sociedade diferenciada funcionalmente, conforme salienta o referido jurista, "os vínculos, relações e sobreposições entre sistemas tornam-se pela primeira vez um problema prático e teórico da sociedade" (CAMPILONGO, 2000, p. 23).

Com o advento do Estado moderno evidenciaram-se as exigências de estabilização de sistemas com funções delimitadas. "A atribuição de papéis distintos e específicos aos sistemas jurídico, político e econômico, paradoxalmente cria as condições para que se pense não só na autonomia dos sistemas, mas também nos seus entrelaçamentos".

Com o sistema jurídico dá-se o mesmo. [...] as grandes categorias do constitucionalismo moderno constroem as bases estruturais para a autonomia funcional do direito: divisão de poderes, princípio da legalidade, igualdade perante a lei, Estado de direito, personalidade jurídica, garantias das minorias, etc., são exemplos dessas ações. Mas as Constituições, se de um lado fornecem as ferramentas para o fechamento operativo do direito, de outro também são o mecanismo da abertura cognitiva do direito para a política. No Estado de Direito, o sistema jurídico fornece respostas legais aos problemas da política. Isso não significa ignorância ou insensibilidade pela política. Ocorre que os problemas da política são traduzidos, deslocados e selecionados pelo sistema jurídico com critérios particulares e internos a esse sistema. Enquanto a política opera num quadro de complexidade elevada e indeterminada, o direito atua num contexto de complexidade já reduzida e determinada por limites estruturais mais rigorosos.

Só quando o direito procura limitar a política e a política determinar o direito a 'politização da justiça' e 'judicialização da política' tornam-se problemas relevantes. Sem que se saiba a função específica de um e de outro sistema, não há sentido em se fazer as conexões ou sobreposições. (CAMPILONGO, 2000, p. 24-25)

No plano jurídico, na acepção de José Eduardo Faria (2004, p. xv), de todos os ramos do Direito talvez seja o constitucional o mais impactado pelas transformações econômicas e políticas 
destas últimas décadas. A idéia de constituição, fruto da engenharia política liberal-burguesa do século XIX, pensada como "centro emanador do ordenamento jurídico", o direito constitucional principiou o século XX como sinônimo de segurança e legitimidade. Demarcou os mecanismos de violência monopolizados pelo Estado, "institucionalizando seus procedimentos decisórios, legislativos e adjudicatórios", situou as formas de participação política e definiu o espaço soberano da palavra e da ação "em contextos sociais marcados pelo relativismo ideológico e em cujo âmbito o poder do Estado depende de critérios externos aos governantes para ser aceito como válido".

No limiar do século XXI, contudo, a idéia de constituição cada vez mais é apontada como entrave ao funcionamento do mercado, como freio da competitividade dos agentes econômicos e como obstáculo à expansão da economia. O que ocorreu ao longo desse período? O que explica a metamorfose sofrida pelas constituições contemporâneas, deixando de ser aceitas como condição de legitimidade da ordem jurídico-política para se converter em objeto de um amplo processo de reforma e enxugamento? O que levou a esse refluxo do constitucionalismo e do próprio direito público e a retomada das pretensões hegemônicas do direito privado, especialmente o civil? (FARIA, 2004, p. xv) E contextualizando a influência da economia sobre o sistema jurídico, contaminando todos os demais se Ao final do século passado, os princípios e mecanismos básicos forjados pelo constitucionalismo, como as liberdades fundamentais, o equilíbrio dos poderes e a segurança do direito, alimentavam um projeto jurídico-político considerado capaz de enfrentar a crescente complexidade sócio-econômica gerada pelo capitalismo mercantil. Hoje, com a globalização dos mercados e a internacionalização do sistema financeiro, valores como ganhos incessantes de produtividade, acumulação ilimitada e livre circulação de capitais converteram-se em imperativos categóricos, transcendendo os limites da economia e contaminando todas as demais esferas da vida social. (FARIA, 2004, p. xvi)

A preponderância da lógica do mercado, segundo Faria, contagiando todas as esferas da vida social, atendendo aos imperativos peremptórios do sistema econômico, esvaece a compreensão de uma ordem constitucional submetida a um padrão político e moral.

\begin{abstract}
Anseios e expectativas formadas ao longo de tensos e conflitivos processos de construção e reconstrução política, em cujo âmbito o tipo de sociedade por eles constituído corresponde a uma certa concepção de moralidade, são sumariamente desqualificados e desconfirmados. Daí, em relação a todas essas mudanças, a tentativa de se recuperar a ética no centro das discussões, ao menos do ponto de vista teórico. Mais precisamente, de se retornar às questões sobre o reconhecimento da dignidade humana, da manutenção das redes sociais de produção, dos direitos dos pobres e das minorias, da atribuição ao poder público da responsabilidade pela equalização de oportunidades - enfim, as velhas, porém muitas vezes esquecidas questões de justiça distributiva e do bem comum, que vinculam Estado e cidadania. (FARIA, 2004, p. xvii)
\end{abstract}

Especialmente sobre a inserção da ética no âmbito da política para lograr-se a configuração de uma identidade na democracia, Cittadino (2004, p. 74-76) observa que o tão anunciado "triunfo" da democracia liberal convive com o fim da utopia igualitária, com as constantes violações de direitos humanos, com o sentimento de vazio associado a uma compreensão da política enquanto mera estratégia de engenharia social, com as concepções de "estado mínimo" e de mercado concorrencial que agravam a sensação de desamparo e fragilidade.

Acrescenta que é, em meio a esse contexto histórico complexo, que se pode assistir a um renascimento da filosofia política, centrada nas relações entre ética, direito e política, cuja principal marca é o compromisso indiscutível com os ideais democráticos. A filosofia política, nessa conjuntura histórica, parece ter encontrado a certeza de que já não é possível sobreviver fora de algum padrão de eticidade e de justiça. 
Por outro lado, sublinha Cittadino que a ficção do sujeito pré-político dá lugar agora à intersubjetividade, ou seja, a considerações acerca das relações lingüísticas entre os indivíduos. A filosofia política contemporânea ${ }^{2}$ se defronta com os valores culturais, os mundos plurais, as diversas concepções sobre a vida digna, uma vez que o sujeito racional solitário está morto. É pela via da intersubjetividade, portanto, que se regressa ao mundo da ética, do direito e da política. As diversas correntes travadas no âmbito da filosofia política, envolvendo liberais, ${ }^{3}$

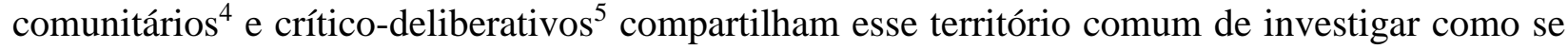
pode compreender a sociedade e quais os elementos e instrumentos que devem atuar nesse processo. A intersubjetividade é, para todos, entretanto, marco de referência da ética e da política, imediatamente vinculada à ideia de construção da democracia (CITADINO, 2004, p. 77).

A representação política, conforme Campilongo (2000, p. 73), está em crise. A divisão do trabalho, idealizada com a democracia liberal, associada à crescente diferenciação social, pensouse, possibilitaria um sistema especializado na tomada de decisões coletivas. Essa atribuição seria própria do sistema político, incumbindo às instituições representativas, em nome da sociedade, decidir sobre o futuro. Imaginou-se a partir das intervenções do sistema político, no dizer de Campilongo, "formatar a economia, o direito, a educação, a saúde, enfim, o mundo". Havia a confiança, sobretudo "na calculabilidade, previsibilidade e racionalidade das decisões políticas".

Apesar de o sistema político desempenhar, hoje, uma função específica, as demais expectativas criadas no plano da sociedade redundaram em eloqüente fracasso, notadamente pela infactibilidade de se decidir no presente como será o futuro. De fato, persiste uma "ingênua convicção na capacidade prestidigitadora do sistema político", determinante da crise da representação hodierna. (CAMPILONGO, 2000, p. 73)

Lembra Campilongo (2000, p. 74) que essa ambição totalizante do sistema político invariavelmente deságua em frustrações. Para os fracassos, encontram-se desculpas simplórias "políticos corruptos, eleitores ignorantes, planejamento deficiente, conseqüências não previstas", sem que se discutam politicamente os limites do sistema político. Esse déficit de representação

\footnotetext{
${ }^{2}$ Há pelo menos quatro correntes doutrinárias, no âmbito da filosofia política, que realizam um debate teórico - Os libertários, os liberais contratualistas, os comunitaristas e os crítico-deliberativos, conforme anota José Eduardo Faria. Gisele Cittadino, na obra em destaque, privilegia três dessas correntes - os liberais, os comunitários e os crítico-deliberativos, que serão objeto de referência. Sobre os libertários, anota Faria: "Os libertários, como Robert Nozick e Friedrich Hayek para quem (a) o aparato coercitivo-jurídico do Estado moderno tem sido utilizado para pressionar o indivíduo e violar seus direitos, inclusive quando o obriga a ajudar o próximo ou o proíbe de desenvolver determinadas atividades para se proteger contra roubos e fraudes, (b) as ideias de justiça social em princípio são um contrassenso por comprometer as liberdades inerentes ao homem, (c) a livre apropriação seria o único princípio de justiça, e (d) só o Estado mínimo, limitado às funções restritas de proteção contra a força e fiscalização do cumprimento de contratos, é justificável" (FARIA, 2004, p. xviii).

${ }^{3}$ Para Faria, os "liberais contratualistas, como John Rawls e Ronald Dworkin, que tratam de questões como as relativas à efetividade e ao reconhecimento dos direitos civis dentro da tradição kantiana, vendo a sociedade como uma combinação da afirmação de identidades e da eclosão de conflitos entre distintas concepções individuais acerca do bem e da vida digna" (FARIA, 2004, p. xviii).

${ }^{4}$ Segundo Faria, "os comunitaristas, como Michael Walzer, Charles Taylor, Michael Sandel e Alasdair MacIntyre, que recuperam a tradição aristotélica ao (a) pôr em xeque a pressuposição de um sujeito universal e não situado historicamente, (b) enfatizar a multiplicidade de identidades sociais e culturais étnicas presentes na sociedade contemporânea e (c) conceber a justiça como a virtude na aplicação de regras conforme as especificidades de cada meio ou ambiente social, criticando os liberais por não serem capazes de lidar com as situações intersubjetivas e de ver os diálogos apenas como uma 'sucessão alternada de monólogos"” (FARIA, 2004, p. xviii-xix).

${ }^{5}$ Os crítico-deliberativos, consoante Faria, "como Jürgen Habermas, formados na tradição hegeliano-marxista, para quem (a) os valores normativos modernos só podem ser compreendidos por meio de leituras intersubjetivas, (b) o princípio do universalismo moral foi encarnado de modo imperfeito nas instituições do Estado constitucional, tendo definhado a ponto de não ser mais do que uma simples palavra, (c) só a razão comunicativa possibilita 'acordos sem constrangimentos' em condições de se irradiar para toda a sociedade, e (d) a diversidade das concepções individuais a respeito da vida digna, apregoada pelos liberais, e a multiplicidade de formas específicas de vida que compartilham valores, costumes e tradições, enfatizada pelos comunitaristas, estão presentes nas democracias contemporâneas, não havendo como optar por uma em detrimento da outra" (FARIA, 2004, p. xix).
}

Revista de Direito Brasileira | Florianópolis, SC | v. 23 | n. 9 | p. 50-62 |Mai./Ago. 2019 
leva a outra falácia, a eventual capacidade do mercado para decidir, substituindo os mecanismos de escolha coletiva. Nesse processo, em vão, sai a política e entra a economia, transferindo-se para o sistema econômico os malogros do sistema político.

A representação política tem estruturas, funções e técnicas de atuação que não the permitem substituir ou suprir as deficiências e lacunas dos sistemas econômico e jurídico. A economia e o direito, por sua vez, operam em bases que não se confundem com as da política. É evidente a enorme relação entre os sistemas. Mas isso não significa que um determine o outro. Política, economia e direito podem trocar prestações, mas nunca atuam com lógica intercambiáveis. Dito de outro modo, os sistemas sociais particulares são funcionalmente isolados e, por isso, só podem ser autocontrolados e auto-estimulados. Só a política pode reproduzir o sistema político. (CAMPILONGO, 2000, p. 76)

De efeito, a representação política, desconhecida dos povos antigos, no dizer de Campilongo (2000, p. 75), é uma característica e um sintoma da sociedade moderna. Com a modernidade, no plano jurídico estabeleceu-se a universalização do Direito, ao passo que no campo político afirmou-se a democratização da participação. "Direito universal é direito posto por decisões. A participação democrática, por seu turno, é premissa para que as decisões coletivas sejam tomadas". Há nesse universo, todavia, "um excesso de possibilidades de escolha, de alternativas para o direito a ser positivado e opções entre diferentes linhas políticas. Só com a modernidade essas condições estruturais foram oferecidas aos sistemas jurídico e político".

"Escolher, selecionar ou optar - numa palavra: decidir" -, isso significa o mesmo que expor, nas condições da sociedade moderna, o direito e a política à contínua transformação, em vista da contingência do processo decisório. A instabilidade, nesse processo, não é defeito e nem vício da democracia moderna. Ao contrário, a abertura para novas alternativas, assim como as incertezas, é da essência da democracia. As instituições representativas são os veículos dessas variações e instabilidades, e, talvez por esse motivo, fala-se de crise da representação política, desde as origens da modernidade. (CAMPILONGO, 2000, p. 76)

Universalização do direito e democratização da política indicam uma importante interdependência entre os sistemas jurídico e político ${ }^{6}$, notadamente porque na democracia representativa a lei deve ser a expressão da soberania popular. Assim, a representatividade condiciona-se às normas definidas pelo direito e vice-versa. O que caracteriza a modernidade, no entanto, como consequiência dessa ampla interação dos sistemas, é a separação de funções entre o

\footnotetext{
${ }^{6}$ Sobre o processo de produção do Direito pelo poder político, numa visão sistêmica, Calmon de Passos enumera: "O processo de produção do Direito pelo poder político democraticamente institucionalizado realiza-se mediante os seguintes procedimentos redutores de complexidade: a) A definição prévia de expectativas compartilháveis, expressas em termos gerais, como primeira redução de complexidade, com o que se viabiliza um mínimo de previsibilidade de como serão compostos os conflitos que vierem a se instaurar na convivência social (o denominado direito material). b) A subsequente disciplina do procedimento a ser adotado pelos interessados e pelos agentes públicos, quando atuarem para prevenir ou solucionar os conflitos de interesses não compostos ou insuscetíveis de ser compostos pelos próprios interessados (o denominado direito processual). c) Por fim, para lograr esses objetivos, a organização da função e definição das competências dos agentes que se farão responsáveis pela composição dos conflitos que vierem a se configurar nas relações sociais (normas de organização). Nesta perspectiva, distingue-se o processo legislativo de produção do Direito, delimitada a função de cada qual deles no espaço amplo da disciplina da solução dos conflitos, específica do jurídico, aos quais, na modernidade, e em decorrência da institucionalização do Estado de Direito Democrático, se acresceu o processo administrativo de produção do Direito. Há, por conseguinte, no processo global de produção do Direito, uma primeira redução de complexidade, de natureza predominante, mas não exclusivamente política, para determinação de um universo de dever ser formalizados em termos genéricos, a par de uma segunda redução de complexidade, de natureza predominante, mas não exclusivamente técnica, a partir daquela, para concreção do que foi definido genericamente, tendo em vista sua aplicação a casos concretos. $\mathrm{O}$ processo político-legislativo disciplina e conforma a primeira função; os processos político-administrativo e políticojurisdicional disciplinam e conformam a segunda função. Tudo isso com atendimento aos preceitos constitucionais" (PASSOS, 2003, p. 87).
} 
direito e a política. As instituições representativas, por isso, podem instituir o direito novo, todavia são compelidas a acatar os limites impostos pelo próprio direito. De igual sorte, os tribunais também podem decidir questões de cunho político inovador, mas no processo judicial são compelidos a observar as fronteiras fixadas pelo sistema político. (CAMPILONGO, 2000, p. 76)

Como visto os sistemas se intercomunicam funcionalmente, mas se submetem à observância dos limites de cada qual, fixados pela Constituição, sob pena de se inviabilizarem reciprocamente e comprometerem a própria democracia.

Nesse horizonte, para Campilongo (2000, p. 82), a modernidade trouxe as idéias de democracia representativa e de Constituição. A democracia constitucional pressupõe a separação entre os sistemas político e jurídico, pois sem essa distinção não há democracia. Como regra isso significa que as decisões políticas não se submetem ao controle judicial, com exceção à constitucionalidade. De igual sorte, as decisões dos tribunais independem do aplauso das assembléias ou da aceitação das praças. Nesse viés adverte para o que se denomina perigo da "juridificação da política" ou da "politização da justiça".

O problema apenas residiria quando os papéis se invertem e os juízes intentam a assumir a condição de representantes do povo, ou os políticos, a pretexto de submeter o Judiciário à lógica do consenso popular procuram amordaçá-lo, criando entraves que não possibilitam o funcionamento tanto do sistema jurídico quanto do sistema político. A Constituição, bem de ver, é o engenho pensado para impedir a politização do direito e proteger a representação das intromissões do Judiciário. É a Constituição que equaliza um sistema em relação ao outro e que delimita o território funcional de cada qual. (CAMPILONGO, 2000, p. 76-77)

O alargamento que se deu a atividade do Estado, segundo Calmon de Passos (2003, p. 90), não importou em alteração substancial da função de julgar, ainda voltada e exclusivamente para a solução dos micro-conflitos. Esse universo apenas se enriqueceu com os novos conflitos "entre os sujeitos de direito em geral e os agentes públicos, também estes limitados, agora, pela lei, por conseguinte suscetíveis de serem questionados perante os órgãos da função jurisdicional”.

\footnotetext{
Não se institucionalizou, por força disso, uma função que às demais se sobrepôs, porque também a função jurisdicional se coloca sob o império da lei e sujeita-se à deslegitimação pelos agentes das demais funções básicas do Estado, como mandatários do povo soberano, e pelo próprio povo, diretamente. Nem lhe foram atribuídas funções políticas, inaceitáveis sem a legitimação específica constitucionalmente reclamada para isso. Nenhuma limitação, por conseguinte, em termos de definição política, sofreu a função legislativa, que permanece como a única legitimada para a formalização da vontade geral, democraticamente expressa e institucionalizada, só modificável pelo processo político, jamais por outra via. Novidade foi sua atribuição, com maior ênfase, a agentes executivos e judiciários, em dimensão diversa da anterior e com alcance diferenciado. (PASSOS, 2003, p. 90)
}

Os agentes políticos e o processo político, consoante Calmon de Passos (2003, p. 91), permanecem como únicos autorizados a formalizar decisões de natureza política fundamental. Os agentes administrativos e jurisdicionais, assim como o processo administrativo e judicial precisam de legitimidade e adequação para formalizar decisões políticas básicas. Nenhuma das três funções - legislativa administrativa e judicial -, no entanto, é livre e soberana para sobreporse à única soberania reconhecível num sistema democrático - a vontade popular, exercida através do processo político constitucionalmente instituído.

Em palavras mais simples - só é Estado de Direito Democrático aquele em que todo e qualquer detentor de poder político só pode exercitá-lo nos limites de sua competência, sujeitando-se à responsabilidade social quando faltar a esse dever. Outrossim, só é Estado de Direito Democrático aquele em que as entidades e órgãos responsáveis pelo exercício do poder político, nos limites de sua competência, submetem-se a recíprocos 
controles, com vistas à atuação tanto quanto possível harmônica, sem prejuízo de sua autonomia (ausência de vínculos hierárquicos) nunca independência (ausência de responsabilidade), o que também vale para o Judiciário, não apenas para o Legislativo e para o Executivo. Donde ser negação do Estado de Direito Democrático toda organização da função jurisdicional que se mostre em desacordo com essas exigências fundamentais. (PASSOS, 2003, p. 92)

Nesse passo, é fundamental ponderar que sem autonomia funcional a representação política e o direito perdem sua capacidade de assegurar procedimentos decisórios que mantenham abertas e crescentes as probabilidades de escolha, variação e construção de alternativas. A representação política, por evidente, não pode tudo e muito menos é capaz de transformar os grandes ideais em realidade. Sem ela, no entanto, perde-se uma peça basilar para a sustentação da democracia.

\section{O SIGNIFICADO DA INTERPRETAÇÃO E O PAPEL DOS JUÍZES NA CRIAÇÃO DO DIREITO}

O problema da criação do Direito (AKEL, 1995), enquanto fenômeno histórico-social, segundo Wolkmer (2000, p. 173), leva a duas expressões técnico-formais que dão plena efetividade ao Direito positivo, que são a lei e a jurisprudência. Em torno dessas duas principais fontes jurídicas sobressaem duas orientações doutrinárias extremamente significativas: a chamada Escola Clássica, ligada à tradição jurídica latino-românica que identifica o Direito com a lei escrita - o jus scriptum; e a representada pela cultura jurídica da Common Law, cunhada como Escola Jurisprudencial.

O legalismo formalista evidentemente ignora a importância das decisões judiciais como fonte do direito e desconsidera o fato de que a lei não contém todo o Direito. Conforme salienta Wolkmer (2000, p. 174), ao juiz compete muito mais a criação do Direito do que a mera interpretação e aplicação da lei, porquanto ele exerce uma função criadora extremamente importante, na medida em que contribui para o aperfeiçoamento e a perpetuação contínua da ordem jurídica.

No tocante à jurisprudência, é consabido que a uniformidade e constância das decisões, assim como o repertório de julgados análogos dos tribunais, são importantes instrumentalizações do direito positivo no domínio das relações sociais de um modo de produção vigente (STAFFEN, 2015, p. 288). A força criadora da jurisprudência tem se revelado importante mesmo nos países de tradição no direito escrito (Civil Law), onde os denominados "precedentes judiciais" mais e mais têm sido invocados por advogados e juízes (CASTRO, 1968, p. 118). Essa acepção é irrefutável pelo menos em relação à sumula vinculante e aos temas jurídicos aprovados pelos Tribunais superiores (erigidos em sede de Repercussão Geral e de Recursos Repetitivos), dado o seu caráter normativo e hierarquizante (cogente).

O ponto fundamental de gravitação de toda a criação judicial, seja nos parâmetros da Common Law, seja nos sistemas jurídicos de direito codificado, advém da resolução de casos particulares e não na formulação de regras gerais e abstratas, mesmo porque a criação judicial enunciada por decisões dos juízes nos tribunais representa a fonte autêntica do direito objetivado. (WOLKMER, 2000)

Neste sentido, a doutrina clássica da Separação dos Poderes, consagrada pelo liberalismo político, tende a balizar a tarefa do juiz, reduzindo-o a um mero aplicador das regras do sistema jurídico dominante e restringindo a função jurisprudencial aos estreitos horizontes de uma "simples máquina de silogismos". Nesta linha de entendimento, os legalistas clássicos não consideram o exercício jurisdicional como um terceiro poder essencial do Estado, negando-lhe o tratamento que é dispensado aos outros dois órgãos vinculados à categoria de ativamente 
políticos (Legislativo e Executivo) e que dispõem de função reguladora e criadora. O Judiciário, de seu turno, como poder não-político, é relegado à simples função de execução e aplicação dos ditames dos poderes políticos. Nessa esteira, a criação do Direito é atributo exclusivo do Legislativo, estando o juiz inteiramente submetido a esses parâmetros, de modo a transformar a independência jurisdicional numa mera ficção. (WOLKMER, 2000, p. 177)

O juiz, na verdade, tem um papel bem maior do que lhe é atribuído falsamente pelo legalismo, já que o monopólio legislativo, em matéria de elaboração e fixação do direito, é falacioso. O juiz, em verdade, é independente na atividade jurisdicional, e como tal, pode estabelecer as normas e as regras de aplicação necessárias, uma vez que, em relação à lei, não se caracteriza jamais pela passividade e nem tampouco a lei será considerada elemento exclusivo na busca de soluções justas aos conflitos. A lei não é a medida exata que assegura a estabilidade e a continuidade do direito. Havendo antinomia entre lei e os princípios fundamentais da ordem jurídica, o resguardo e a manutenção destes princípios incumbem ao juiz e não ao Poder Legislativo. (WOLKMER, 2000, p. 177-178)

Neste tocante, vale a advertência de Alexy (2001) de que a lei não vale mais por si, mas depende da sua adequação aos direitos fundamentais. Nessa perspectiva, se antes era possível asseverar que os direitos fundamentais eram circunscritos à lei, hoje é apropriado concluir que as leis devem estar em consonância com os direitos fundamentais.

Para Marinoni (2005, p. 25), o princípio da legalidade, com a assunção do Estado constitucional, exige que a ele se dê uma nova configuração, compreendendo-se que, se antes esse princípio era formal, atualmente ele tem conteúdo substancial, pois requer a conformação da lei com a Constituição e, especialmente, com os direitos fundamentais. Essa conformação da lei ou da legislação faz com que o juiz crie, mediante a interpretação ou o controle de constitucionalidade, uma norma jurídica para justificar a sua decisão.

Essa compreensão crítica, consoante Marinoni (2005, p. 26), já é uma tarefa de concretização, uma vez que "a lei não é mais objeto, mas sim componente que vai levar à construção de uma nova norma, vista não como texto legal, mas sim como o significado da sua interpretação e, portanto, como um novo ou outro objeto".

Comparando-se a sua atividade com a de um fotógrafo, o jurista não deve mais apenas revelar as palavras da lei, mas sim projetar uma imagem, corrigindo-a e adequando-a aos princípios de justiça e aos direitos fundamentais. Aliás, quando essa correção ou adequação não for possível, só restará ao jurista demonstrar a inconstitucionalidade da lei, ou - ainda de forma figurativa - descartar a película por ser impossível encontrar uma imagem adequada. (MARINONI, 2005, p. 26)

Por outro lado, não há como negar, hoje, a eficácia normativa ou a normatividade dos princípios de justiça. Atualmente, para Marinoni (2005, p. 26), esses princípios e os direitos fundamentais têm qualidade de normas jurídicas e, assim, estão muito longe de significar simples valores. Nesse viés, mesmo os princípios constitucionais não explícitos e os direitos fundamentais não expressos têm plena eficácia jurídica. Essa tomada de consciência, para Luiz Roberto Barroso (2003, p. 29), é muito importante para concluir que tais princípios e direitos conferem unidade e harmonia ao sistema, "não dando alternativa ao juiz e ao jurista senão colocar a lei na sua perspectiva. Vale dizer que as normas constitucionais são vinculantes da interpretação das leis".

A função jurisdicional, conforme salienta Wolkmer, transcende a modesta e subserviente atividade de aquiescer aos caprichos e à vontade do legislador, porquanto como poder criador, o juiz não constitui um simples técnico que mecanicamente aplica o direito em face de litígios reais. Busca, em verdade, solucionar os conflitos de interesse entre sujeitos individuais e coletivos, operando juridicamente como uma verdadeira força de expressão social que se define pelo exercício de uma função capaz de explorar as fissuras, as antinomias e as contradições da ordem jurídica. $\mathrm{O}$ magistrado, por conseguinte, não se limita à atividade de natureza meramente 
interpretativa ou dedutiva daquilo que lhe é dado. Sua tarefa versa na revelação de uma forma jurídica mais adequada, mais equânime e mais justa.

Consequentemente, a sentença judicial emanada do Juiz adquire, não só a validade formal como tambe incorporadas pelo legislador do Direito positivo. O papel do Juiz é acentuadamente marcante, não só como recriador através do processo hermenêutico, mas também como adaptador das regras jurídicas às novas e constantes condições da realidade social. É contribuindo para a transformação e democratização contínua da ordem jurídica positiva que o Juiz, em seu mister interpretativo, insere a semente vivificadora e inspiradora do Direito justo. (WOLKMER, 1991, p. 67)

Há evidentemente preocupação em definir critérios-limite de natureza ético-jurídica para demarcar a ação jurisdicional e os poderes do juiz. O limite, por certo, é o razoável. Há o risco de que poderes ilimitados possam gerar um governo dos magistrados ou a ditadura do Judiciário. Sobre o assunto, Benjamin Cardozo (1978), representante do realismo da tradição jurídicoburguesa norte-americana, observa:

As excentricidades dos Juízes se equilibram. Um Juiz considera os problemas do ponto de vista da hist Juiz, mesmo quando livre, não o é totalmente. Ele não pode inovar a seu bel-prazer. Não é um cavaleiro-errante, vagando à vontade em busca de seu próprio ideal de beleza ou de bondade. [...] Não deve ceder ao sentimento espasmódico, à benevolência indefinida e desgovernada. (WOLKMER, 2000, p. 179)

Hoje é desprezível a doutrina que considera o processo mera técnica instrumentalmente conexa ao direito material, como adverte Dinamarco (2005, p. 61). Exorta, no entanto, que ele é técnica sim, mas técnica que deve ser informada pelos objetivos e ideologias revelados na ciência processual e levada a efeito com vista à efetivação do valor do justo. E acrescenta:

Existem ainda outros compromissos do juiz moderno, entrelaçados com os demais objetivos de sua própria função. Ele deve ter consciência das destinações políticas $e$ culturais do sistema que opera, para que o exercício da jurisdição possa dar efetividade a certos valores relevantes para a sociedade como um todo - valores que se expressam nos chamados escopos do processo. O escopo social de educação para o exercício de direitos próprios e respeito aos direitos alheios aconselha o juiz a dispensar a tutela jurisdicional com a possível celeridade; o escopo político de preservação da moralidade administrativa há de estar presente na condução das ações populares; de um modo geral, o escopo também político de dar efetividade aos valores acatados pelo direito objetivo recomenda plena participação do juiz nos processos sob sua direção, tomando razoáveis iniciativas probatórias, dialogando racionalmente com os litigantes, dispondo medidas urgentes que evitem a consumação de males irremediáveis e capazes de frustrar o exercício útil da jurisdição etc.(DINAMARCO, 2005, p. 61)

O tema, pelo visto tem importantes inflexões tanto pela teoria política quanto pela teoria jurídica, de modo a instigar o corpo de magistrados e a sociedade política para um debate permanente sobre os limites da atividade jurisdicional, para a preservação dos valores constitucionais e da democracia, no Estado democrático de direito.

\section{CONCLUSÃO}

O dever fundamental do juiz, de fato, é realizar justiça. Para tanto deve afastar-se dos legalismos estéreis que cerceiem sua liberdade de criar na sentença o Direito para o caso concreto; de conferir o caráter injuntivo que lhe permite impender, na sentença, seu papel institucional de construtor de uma ordem jurídica justa, comprometida com os valores e os 
princípios ético-sociais que a sociedade pretende preservar.

Consoante Coelho (1992, p. 28), a resistência às leis injustas deve começar pelos juízes, o segmento da sociedade que, em razão de conquistas que logrou após muita luta e arrostando muita incompreensão, "transformou-se não somente no derradeiro refúgio das reivindicações sociais, mas no único setor realmente aparelhado para resistir aos desmandos e às tentativas autoritárias".

Anatóle France, Prêmio Nobel de Literatura de 1921, em texto sobre o tema "A Lei é Morta o Juiz é Vivo", pugna por trazer a Justiça para o social, ultrapassando as condições limitadoras de seu momento de produção, quando proverbializa: "Enquanto a sociedade for fundada na injustiça, as leis terão por função defender e sustentar a injustiça".

Daí acrescer em muito a responsabilidade do juiz perante a sociedade e a cidadania, como efetivo agente político e responsável por uma parcela significativa do poder estatal, no exercício legítimo de seu papel de garantidor da Constituição e da ordem constitucional, a serviço do Estado democrático de direito.

\section{REFERÊNCIAS}

ABREU, Pedro Manoel. Processo e Democracia: O processo jurisdicional como um locusda democracia participativa e da cidadania inclusiva no estado democrático de direito. São Paulo: Conceito Editorial, 2011.

ABREU, Pedro Manoel; STAFFEN, Márcio Ricardo. Reflexões sobre o modelo participativo de processo jurisdicional brasileiro. Revista Scientia Iuris, Londrina, v. 16, n. 02, jul-dez. 2012.

AKEL, Hamilton Elliot. O poder judicial e a criação da norma individual. São Paulo: Saraiva, 1995.

ALEXY, Robert. Los derechosfundamentalesenel Estado Constitucional Democrático: Los fundamentos de losderechosfundamentales. Madrid: Trotta, 2001.

BARROSO, Luís Roberto. O Direito Constitucional e a Efetivação de suas Normas: limites e possibilidades da Constituição brasileira. 5. ed. Rio de Janeiro: Renovar, 2001.

BARROSO, Luís Roberto. Fundamentos teóricos e filosóficos do novo direito constitucional brasileiro. A nova interpretação constitucional. Rio de Janeiro: Renovar, 2003.

BIELSA, Rafael A. Transformacióndelderechoenjusticia:Ideas para una reforma pendiente. Buenos Aires: 1993.

CAMPILONGO, Celso Fernandes. Política, Sistema Jurídico e decisão judicial. São Paulo: Max Limonad, 2000.

CAMPILONGO, Celso Fernandes. O Direito na sociedade complexa. São Paulo: Max Limonad, 2000.

CARDOZO, Benjamin. A natureza do processo e a evolução do direito. 3. ed. Porto Alegre: Ajuris-9, 1978.

CASTRO, Amílcar de. Direito internacional privado. 3. ed. Rio de Janeiro: Forense, 1968, v. 2. 
CITTADINO, Gisele. Pluralismo, Direito e Justiça Distributiva: Elementos da Filosofia Constitucional Contemporânea. 3. ed. Rio de Janeiro: Lumen Juris, 2004.

COELHO, Luiz Fernando. "Do Direito Alternativo". Revista de Direito Administrativo. São Paulo: Acadêmica, n. 1, 1992.

DINAMARCO, Cândido Rangel. Instituições de Direito Processual Civil. 3. ed. rev. e atual. São Paulo: Malheiros, Vol. I.

DROMI, Roberto. El Poder Judicial. Mendoza: 1984.

EISENBERG, José. "Pragmatismo, Direito Reflexivo e Judicialização da Política". In: VIANNA, Luiz Werneck (org.). A democracia e os três Poderes no Brasil. Belo Horizonte: UFMG; Rio de Janeiro: IUPERJ/FAPERJ, 2002.

FARIA, José Eduardo. “Prefácio”. In: CITTADINO, Gisele. Pluralismo, Direito e Justiça Distributiva: Elementos da Filosofia Constitucional Contemporânea. 3. ed. Rio de Janeiro: Lumen Juris, 2004.

GARAPON, Antoine. O Juiz e a Democracia: o guardião das promessas. Trad. Maria Luíza de Carvalho. 2. ed. Rio de Janeiro: Revan, 2001.

LAMBERT, Edouard. Le GouvernementdesJuges et laLuttecontrelaLégislationSocialeauxEtatsUnis. Paris: Giard, 1921.

LEMOINE, Yves. Le Complot des Juges. Paris: Félin, 1993.

LOEWENSTEIN, Karl. Teoria de la Constitución. 2. ed. Barcelona: Ariel, 1970;

CAMPILONGO, Celso Fernandes. "The Judicialization of Politics". In: International Political Science Review. Londres, v. 15, n. 2, abr. de 1994.

LUHMANN, Niklas. Legitimação pelo procedimento. Brasília: Universidade de Brasília, 1980.

MARINONI, Luiz Guilherme. “A Jurisdição no Estado Contemporâneo”. In: MARINONI, Luiz Guilherme (Coord.) Estudos de Direito Processual Civil. São Paulo: Revista dos Tribunais, 2005.

PASSOS, J.J. Calmon de. Direito, poder, justiça e processo: julgando os que nos julgam. Rio de Janeiro: Forense, 2003.

SHAPIRO, Martin; SWEET, Alec Stone. On Law, Politics and Judicialization. Oxford: Oxford University Press, 2002.

SILVA, Carlos Augusto. O Processo Civil como Estratégia de Poder: Reflexo da Judicialização da Política no Brasil. Rio de Janeiro: Renovar, 2004.

SOUSA JÚNIOR, José Geraldo de. “Os íntegros Juízes ou Desafios à Magistratura”. “Jornal Estado de Direito”. In: http://www.estadodedireito.com.br/2013/08/06/os-integros-juizes-oudesafios-a-magistratura. Acesso em: 15 abr. 2019. 
STAFFEN, Márcio Ricardo. Estado, constituição e juizados especiais federais. Rio de Janeiro: Lumen Juris, 2015.

TOBEÑAS, José Castán. La formulación judicial del derecho. 2. ed. Madrid: Instituto Editorial Reus, 1954.

VALLINDER, Torbjörn (Org.). The Global Expansion of Judicial Power: The Judicialization of Politics. Nova York: New Iork University Press, 1995.

VIANNA, Luiz Werneck et al. Corpo e Alma da Magistratura Brasileira. 3. ed. Rio de Janeiro: Revan, 1997, 334 p.

VIANNA, Luiz Werneck et al. A judicialização da política e das relações sociais no Brasil. Rio de Janeiro: Revan, 1999.

VIANNA, Luiz Werneck et al (org.). A democracia e os três Poderes no Brasil. Belo Horizonte: UFMG; Rio de Janeiro: IUPERJ/FAPERJ, 2002.

WOLKMER, Antônio Carlos. Ideologia, Estado e Direito. 3. ed. rev. e ampl. São Paulo: Revista dos Tribunais, 2000.

WOLKMER, Antônio Carlos. Introdução ao pensamento jurídico crítico. São Paulo: Acadêmica, 1991.

ZAFFARONI, Eugenio Raúl. Poder Judiciário: Crise, Acertos e Desacertos. Trad. Juarez Tavares. São Paulo: Revista dos Tribunais, 1995. 